УДК 373.5.016:53

Головко Микола Васильович

кандидат педагогічних наук, доцент, старший науковий співробітник, заступник директора 3 наукової роботи

Інститут педагогіки НАПН України, м. Київ, Україна

m.golovko@ukr.net

\title{
ГЕНЕЗА ВПРОВАДЖЕННЯ ІНФОРМАЦЙНО-КОМУНІКАЦИЙНИХ ТЕХНОЛОГІЙ У ФІЗИЧНІЙ ОСВІТІ: ВІД КОМП'ЮТЕРНОЇ ПІДТРИМКИ НАВЧАННЯ ДО ФОРМУВАННЯ КЛЮЧОВИХ І ПРЕДМЕТНИХ КОМПЕТЕНТНОСТЕЙ
}

\begin{abstract}
Анотація. У статті на основі історико-методичного аналізу обгрунтовуються особливості процесу впровадження інформаційно-комунікаційних технологій у навчання фізики, розвитку комп'ютерного дидактичного забезпечення. Висвітлюється генеза наукових засад і механізмів їх реалізації у вітчизняній теорії і методиці навчання фізики, вплив на формування комп'ютерно-орієнтованого середовища і якісну зміну ролі суб'єктів навчального процесу. Актуалізується доцільність подальших дидактичних досліджень означеної проблеми у зв'язку з пріоритетністю комп'ютерно-орієнтованих технологій у формуванні ключових і предметної компетентностей учнів загальноосвітньої і вищої шкіл у процесі навчання фізики.
\end{abstract}

Ключові слова: розвиток теорії і методики навчання фізики; засоби інформаційнокомунікаційних технологій; ключові та предметні компетентності.

\section{1. ВСТУП}

Постановка проблеми. Як свідчить світовий i вітчизняний досвід, результативність функціонування сучасного освітнього закладу будь-якого типу визначається багатьма показниками, серед яких важливе місце займає ступінь упровадження в навчальний процес інформаційно-комунікаційних технологій (IКТ). Це, у свою чергу, співвідноситься 3 формуванням комп'ютерно-орієнтованого навчального середовища, яке забезпечує розвиток предметних $\mathrm{i}$ ключових компетентностей, і створює умови для подальшої успішної навчальної і професійної діяльності випускника загальноосвітніх навчальних закладів.

Державний стандарт базової i повної загальної середньої освіти визначає інформаційно-комунікаційну компетентність як ключову і передбачає внесок кожного навчального предмету у їі формування [3]. Для компетентнісного навчання фізики, яке потребує якісної візуалізації, моделювання та динамічного аналізу різноманітних явищ i процесів, проблема науково обгрунтованого впровадження інформаційнокомунікаційних технологій є особливо актуальною.

Аналіз останніх досліджень і публікацій. Важливість окресленої проблеми в дидактиці фізики підтверджується системними дослідженнями, спрямованими як на обгрунтування теоретико-методологічних засад використання IКТ, так і створення на їх основі новітніх освітніх технологій, що забезпечують досягнення цілей фізичної освіти. Результатом фундаментальних досліджень В. Ю. Бикова стало обгрунтування комп'ютерно орієнтованої складової педагогічної технології як відображення формалізованої моделі компонентів змісту навчання і методики його реалізації програмними засобами і комп'ютерними комунікаційними мережами для постановки і розв'язання дидактичних завдань [1]. У працях О. І. Іваницького окреслено коло 
дидактичних завдань, пов'язаних із цим процесом, i запропоновано шляхи їх розв'язання [9]. Проблема застосування у дидактиці фізики системно-процесуального підходу, характерного для інформатичної науки, який забезпечує можливість конструювання моделей навчального процесу як динамічних систем отримала розвиток у працях Ю. О. Жука, О. М. Соколюк, М. І. Шута [ 8, 11, 12]. Роль ІКТ у формуванні ключових i предметних компетентностей майбутніх учителів фізики й учнів загальноосвітніх навчальних закладів обгрунтована в працях В. Ф. Заболотного, О. П. Пінчук, О. М. Соколюк [7, 13]. Попри це, з 1995 року виконано більше двадцяти дисертаційних досліджень 3 методики навчання фізики в середній і вищій школах, у яких розроблено теоретичні і практичні аспекти цього питання. Отже, проблему інформаційно-комунікаційних технологій у навчанні фізики можна розглядати як самостійний і один із пріоритетних напрямів сучасної дидактики фізики.

Мета статті. Тенденції розвитку методики навчання фізики в умовах поглиблення інформатизації освіти визначають необхідність пошуку механізмів науково обгрунтованого використання можливостей сучасних інформаційних технологій.

У дослідженні реалізується спроба цілісного аналізу історико-методичних особливостей запровадження комп'ютерно орієнтованих технологій у навчальновиховний процес 3 фізики не лише 3 точки зору узагальнення теоретичного i практичного досвіду, а й перспектив створення сучасних дидактичних систем, спрямованих на реалізацію цілей фізичної освіти, зумовлених запитами інформаційного суспільства.

\section{2. МЕТОДИКА ДОСЛІДЖЕННЯ}

Комп'ютерно орієнтовані педагогічні технології стають невід'ємною частиною сучасної освіти. Особливо актуальними вони є для ефективної організації навчальновиховного процесу з фізики, у якому відбувається опанування не лише змісту, а й методів дослідження явищ i процесів, широке використання засобів шкільного фізичного експерименту, формування модельних уявлень. Інформаційно-комунікаційні технології у навчанні фізики дають можливість систематизувати й опрацьовувати, а за наявності відповідного обладнання й сервісів і фіксувати результати фізичного експерименту, створювати й аналізувати комп'ютерні моделі явищ, які не можуть бути відтворені в умовах шкільної фізичної лабораторії. Створюються принципово нові умови і можливості для здійснення учителем неперервного управління пізнавальною діяльністю i моніторингу навчальних досягнень 3 фізики, реалізації авторських методичних систем, розвитку творчого професійного потенціалу педагогічного працівника. 3 огляду на це, процес запровадження ІКТ є поліаспектним й охоплює не тільки технологічні, а й процесуальні аспекти, впливає на розвиток когнітивної сфери його суб'єктів. Розвиток цього процесу становить науковий інтерес, оскільки виявлені закономірності визначають його особливості й логіку в контексті подальшого розвитку методів, форм та засобів навчання фізики.

Основними методами такого дослідження доцільно обрати онтологічний, середовищний та функціональний аналіз становлення і розвитку інформаційнокомунікаційних технологій у системі фізичної освіти. Перший забезпечує адекватне співвіднесення наукових понять, що описують досліджуване педагогічне явище на різних етапах, розуміння їх еволюції. Другий і третій - дають можливість виявляти внутрішні і зовнішні чинники навчального середовища, вплив досліджуваних явищ на зміну суспільних запитів й оцінок, розвиток теорії і практики навчання фізики. 


\section{3. РЕЗУЛЬТАТИ ДОСЛІДЖЕННЯ}

Запровадження інформаційно-комунікаційних технологій у навчально-виховний процес з фізики середньої і вищої шкіл бере свій початок із середини 1960-х років, коли на хвилі бурхливого розвитку вітчизняної кібернетики в загальноосвітніх і вищих навчальних закладах починають використовуватися перші електронно-обчислювальні комплекси для організації програмованого навчання. Проте реальна можливість включення засобів комп'ютерної підтримки у систему дидактичного забезпечення фізичної освіти видалася лише у другій половині 1980-х років, коли почала реалізовуватися державна програма інформатизації освіти.

У другій половині 1990-х років загальні підходи щодо розв'язання проблеми інформатизації освіти запроваджуються в практику часткових дидактик, зокрема, й дидактики фізики. На цьому етапі науковці розглядають ІКТ як засіб удосконалення традиційних методичних систем навчання фізики. Одним із перших дисертаційних досліджень 3 окресленої проблеми стала робота Ю. О. Жука «Розв'язування дослідницьких задач з фізики з використанням нових інформаційних технологій» (1995 р.), у якій автором розроблено методику розвитку продуктивного мислення учнів у процесі навчання розв'язування дослідницьких задач 3 фізики 3 використанням комп'ютерних технологій [8]. Активно досліджуються питання вдосконалення навчального фізичного експерименту засобами інформаційних технологій (Желюк О .М., 1996 р.; Сосницька Н. Л., 1998 р.; Муляр В. П., 1999 р.) у середній школі. Зокрема розроблялися й апробувалися в практиці загальноосвітньої школи системи навчальних комп'ютерних моделей, педагогічних програмних засобів для комп'ютерної підтримки навчання фізики. Обгрунтовується доцільність формування основних фізичних понять 3 використанням можливостей комп'ютерної техніки, умови використання комп'ютера у вивченні фізики, методика використання навчальних комп'ютерних програм у навчальному процесі 3 фізики. У дисертації А. М. Сільвейстра «Активізація пізнавальної діяльності учнів на уроках вивчення нового навчального матеріалу 3 електродинаміки з застосуванням комп'ютера» (2000р.) розроблено методичну систему активізації пізнавальної діяльності учнів на уроках вивчення нового навчального матеріалу з фізики із застосуванням комп'ютера, апробовано систему педагогічних програмних засобів з фізики.

Теоретичні дослідження проблеми використання засобів інформаційнокомунікаційних технологій у навчанні фізики поступово поєднуються 3 активною роботою зі створення педагогічних програмних засобів з фізики нового покоління. У перших дисертаційних дослідженнях з означеної проблеми пропонувалися авторські розробки фрагментів електронних засобів навчального призначення, здебільшого, як ілюстрація практичного втілення отриманих наукових результатів, Також як елемент методичних систем широко використовувалися педагогічні програмні засоби загальнонавчального призначення (наприклад, GRAN). На початку 2000-х років розпочинаються грунтовні роботи зі створення специфічного програмно-методичного забезпечення навчально-виховного процесу з фізики, що базувалося на широкому використанні можливостей інформаційно-комунікаційних технологій.

Важливою особливістю розвитку дидактики фізики на цьому етапі стає обгрунтування питань використання IКТ і розроблення практичних механізмів їх запровадження в навчальний процес загальноосвітньої і вищої педагогічної шкіл. Як показує аналіз цього процесу, такі дослідження важливі не скільки своїми практичними результати для широкого застосування, a, у першу чергу, їх прогностичною роллю. Зважаючи на те, що повнофункціональне забезпечення масової школи комп'ютерною технікою залишалось бажаною перспективою, а можливість розроблення електронних 
засобів навчального призначення для масової школи обмежувалася відсутністю відповідних програмно-апаратних ресурсів, науковці активно працювали над розробленням цих питань, закладаючи науково-організаційні і методичні підвалини майбутніх досліджень.

У працях О. І. Бугайова, В. Ф. Заболотного, В. С. Коваля, В. І. Сумського зроблено перші спроби визначити загальні підходи щодо перспектив створення i використання електронних підручників 3 фізики в загальноосвітній школі. Обгрунтовувалися можливості використання дидактичного забезпечення 3 фізики на електронних носіях, основні функції педагогічних програмних засобів, особливості їх архітектури і психолого-педагогічні вимоги до них [5].

Доцільно відзначити, що на цьому етапі розвитку комп'ютерно орієнтованих технологій навчання фізики важливе значення мали теоретичні i практичні напрацювання творчого колективу кафедри методики викладання фізики та інформатики Вінницького державного педагогічного університету під керівництвом В. І. Сумського та В. Ф. Заболотного. Саме тут створюються одні цілісні педагогічні програмні засоби з фізики для загальноосвітньої і вищої шкіл. Одна 3 перших плідних спроб теоретико-методологічного обгрунтування використання комп'ютера як ефективного засобу сучасних інформаційних технологій у навчанні фізики була здійснена В. І. Сумським. У монографічному дослідженні автор аналізує дидактичні можливості комп'ютерної техніки у навчальному процесі 3 фізики, основні організаційні форми іiі використання, обгрунтовує психолого-педагогічні аспекти запровадження комп'ютерно орієнтованих систем, а також розробляє психологопедагогічні вимоги до сучасних педагогічних програмних засобів з фізики. Уперше системно розглядається проблема створення методичної системи підготовки майбутнього вчителя до використання сучасних інформаційних технологій у подальшій професійній діяльності [14].

Ці напрацювання дозволили досить швидко перевести проблему розроблення комп'ютерного дидактичного забезпечення у практичну площину. Важливі кроки у цьому напрямі, що значною мірою визначили становлення IКТ навчання фізики в загальноосвітній школі, були зроблені на державному рівні у 2003-2006 роках. Програма створення електронних засобів навчального призначена, реалізована Міністерством освіти і науки України, передбачала забезпечення загальноосвітніх навчальних закладів засобами комп'ютерної підтримки базових навчальних предметів в основній і старшій шкоах. Було розроблено біля 50 педагогічних програмних засобів, які після апробації в більш ніж 1500 загальноосвітніх навчальних закладах до цього часу широко й ефективно використовуються в шкільній практиці.

Першими таким продуктами з фізики стали педагогічні програмні засоби «Фізика, 7 кл.», «Фізика, 8 кл.», «Бібліотека електронних наочностей 3 фізики, 7-11 кл.», розроблені підприємством «Квазар-Мікро» за участю науковців Інституту педагогіки Національної академії педагогічних наук України (авторський колектив у складі О. І. Бугайова, М. В. Головка, В. С. Коваля) [2].

Практика створення педагогічних програмних засобів, їх просування та функціонування в навчальному середовищі показали суттєві відмінності традиційних i комп'ютерно орієнтованих методичних систем. «Проникаючий» характер ІКТ зумовив ситуацію, коли запити шкільної практики, досвід використання педагогічних програмних засобів із фізики випереджали розвиток наукового супроводу цього процесу.

Тому актуалізувалася необхідність дидактичного обгрунтування створення технологій i засобів єдиного інформаційного освітнього простору, ресурсне забезпечення якого відповідало б сучасним вимогам й ефективно використовувало 
інформаційно-комунікаційні технології. Теоретичні засади запровадження IКТ у навчанні фізики учнів загальноосвітньої школи на рівні розв’язання дидактичної проблеми отримали розвиток у дослідженнях О. I. Іваницького. Він обгрунтував дидактичні принципи використання локальних (комп'ютерне моделювання, комп'ютерні дидактичні матеріали, комп'ютерний контроль знань, застосування комп'ютерних баз даних, комп'ютерні лабораторні роботи) і загальних (експертні навчальні системи, дистанційне навчання фізики, віртуальне навчання фізики) комп'ютерних технологій навчання фізики [9].

Методичні системи навчання фізики, що базувалися на монотехнологіях комп'ютерного навчання хоча й набували значного поширення, мали достатньо локальний вплив, оскільки спрямовувалися лише на модернізацію традиційної системи навчання фізики в загальноосвітній школі. Намагання розширити їх вплив за такого підходу без докорінних змін методології цілепокладання, формування та реалізації змісту шкільної фізичної освіти, зосередження уваги на задоволені пізнавальних потреб учнів спричиняли протиріччя між усталеною класно-урочною, предметно-тематичною системою навчання фізики і концепцією широкого запровадження IКТ, що мали потужні дидактичні можливості.

Домінування локальних або «проникаючих» комп’ютерно орієнтованих технологій навчання фізики було цілком логічним для цього етапу розвитку методики використання ІКТ. Наразі їх роль розглядалася, перш за все, у контексті зміни засобів навчання. Використання комп'ютерної і мультимедійної техніки відкривало широкі можливості для розширення поля пізнавальної діяльності учнів у процесі навчання фізики і більш ефективного управління нею. Такий підхід орієнтований більшою мірою на технологізацію навчального процесу, коли проблема забезпечення шкільного кабінету фізики засобами мультимедія була особливо гострою, а виробництво електронних засобів навчального призначення для масової школи лише розпочиналося.

Разом 3 тим, у дидактиці фізики розпочинається системна робота 3 наукового обгрунтування наукових засад використання наявних електронних засобів навчального призначення, програмно-методичні комплекси з метою вдосконалення традиційних, а також розроблення нових дидактичних систем навчання фізики. Разом 3 тим, шкільна практика показала загострення зазначених вище протиріч. Зокрема, за досить значного насичення ринку педагогічних програмних засобів 3 фізики вітчизняного i закордонного виробництва, виявлялася локальність їх використання за традиційної організації навчального процесу 3 фізики. Навіть за умови реалізації основних принципів побудову навчальних інформаційних систем, реалізованих у засобах навчального призначення 3 фізики (наприклад, відкритість, модульність і т. д.) їх використання не мало системного характеру. Авторські дидактичні системи навчання потребували не тільки і не скільки більш досконалих засобів навчання, а, у першу чергу, нових принципів щодо подання змісту і зміни способів організації навчальнопізнавальної діяльності учнів з фізики.

Теоретичні і практичні напрацювання з проблеми запровадження IКТ у навчання фізики, перший досвід широкого використання педагогічних програмних засобів давали можливість поглиблювати дослідження окреслених питань, з метою створення дієвих методичних систем навчання фізики 3 провідною роллю засобів нового покоління. Цей напрям було продовжено у дослідженнях I. Л. Семещука (2005 р.), С. К. Мисловської (2007р.), Н. А. Мисліцької (2007р.), які запропонували комп'ютерно орієнтовані методичні системи формування основних понять шкільного курсу фізики, створення i використання комп'ютерних моделей 3 урахуванням психологопедагогічних й ергономічних вимог, навчально-методичних комплексів. У кандидатській дисертації Л. В. Непорожньої (2008р.) обгрунтовано й реалізовано 
методичну систему навчання хвильової i квантової оптики в загальноосвітніх навчальних закладах на профільному рівні з використанням комп'ютерних технологій. Основою запропонованої методики визначено особистісно зорієнтований підхід у навчанні фізики, а iї експериментальна перевірка показала якісний вплив на вдосконалення процесу формування предметної компетентності учнів старшої школи 3 фізики, активізацію дослідницької і творчої навчально-пізнавальної діяльності. Це було одне 3 перших досліджень, у якому автор встановлював кореляцію між ефективністю застосування засобів інформаційно-комунікаційних технологій і процесом формування компетентностей учнів старшої школи.

Поглиблення процесів інформатизації шкільної освіти і широке запровадження комп'ютерних засобів навчання зумовили доцільність методологічної переорієнтації загальних підходів. У дидактиці актуалізується підхід, за яким, як відзначає відомий фахівець у галузі інформаційно-комунікаційних технологій академік В. Ю.Биков, виникає необхідність розглядати ІКТ не тільки у контексті засобів навчання нового покоління й удосконалення технологічної складової навчального процесу, а й як механізм кардинального оновлення змістово-цільових аспектів навчального процесу, основу формування нових педагогічних технологій, що базуються на широкому використанні комп'ютерної техніки, визначальний вплив на зміну цілей і відповідне оновлення змісту освіти [1].

Сучасні наукові підходи до проблеми використання інформаційнокомунікаційних технологій у навчанні фізики визначають доцільність перегляду традиційних методів та організаційних форм навчальної діяльності, посилення їх пошукового і дослідницького характеру. Це зумовлює застосування у дидактиці фізики системно-процесуального підходу, характерного для інформативної науки, який забезпечує можливість конструювання моделей навчального процесу як динамічних систем.

Такі дослідження виконані науковцями Інституту інформаційних технологій та засобів навчання НПН України під керівництвом Ю. О. Жука. Їх результати дали можливість виокремити коло дидактичних проблем, що безпосередньо пов'язані із запровадженням IКТ у навчання фізики. Серед них традиційно важливими і такими, що розв'язуються упродовж двох десятиліть, є наукове обгрунтування ефективних засобів організації навчання, раціональне поєднання віртуального i реального фізичного експерименту, різних форм навчально-пізнавальної діяльності учнів. Разом 3 тим, акцентовано увагу на необхідності організації комп'ютерно-орієнтованого середовища, розроблення 3 позицій дидактичної доцільності педагогічних програмних засобів різних типів [10].

Наступним етапом розвитку проблеми використання IКТ стало виокремлення такого напряму, як розроблення методичних систем навчання фізики в умовах комп'ютерно орієнтованого середовища. Особливістю комп'ютерно орієнтованого навчального середовища стає його квазізамкненість або відкритість, за яких навчальна інформація виходить за межі навчального середовища, ускладнюючи його структуру, методи і форми організації взаємодії його суб'єктів. Традиційні моделі навчання фізики доповнюються принципово новими, реалізація яких тісно пов'язана 3 формуванням комп'ютерно орієнтованого середовища.

Зокрема, разом з традиційними формами організації навчання фізики, у яких технічні засоби навчання забезпечують удосконалення особистісного контакту між суб' єктами в умовах інформаційної замкненості навчального середовища, нині можуть функціонувати моделі, у яких взаємодія суб'єктів навчально-виховного процесу 3 фізики реалізується засобами IКТ, використанням локальних комп'ютерних мереж, ресурсів мережі ІІнтернет не тільки для подання навчальної інформації, а й включення 
учителя й учня у процес її активного пошуку й опрацювання. Характерними ознаками такої організації навчання стає розширення можливостей індивідуалізації і диференціації навчання. Водночас значно зростає залежність навчального процесу від таких чинників, як відсутність можливості використання мережі Інтернет, потужність апаратних, програмних, мережних засобів IКТ, збої в їх функціонуванні [12].

Зауважимо, що в умовах розвиненого комп'ютерно орієнтованого середовища відбуваються суттєві зміни структури дидактичного простору. У дослідженнях Ю. О. Жука, Н. П. Дементієвської, О. П. Пінчук, О. М. Соколюк, П. К. Соколова доведено, що застосування ІКТ у навчально-виховному процесі 3 фізики сприяє специфічній декомпозиції навчального середовища, зменшенню чинника особистісного спілкування учасників навчально-виховного процесу, розширенню спектра ефективних методик навчання [12]. Саме тому ІКТ виступають основним чинником забезпечення індивідуальної і колективної навчальної діяльності з фізики. Наразі на перший план виходить не стільки методика навчання того чи іншого елементу змісту, а структура $\mathrm{i}$ зміст організаційних впливів, які забезпечують координацію, як правило, цілком самостійної навчальної діяльності учня 3 незначним рівнем управлінських впливів 3 боку вчителя фізики. Тому в умовах використання IКТ особливе значення мають структура і зміст інструктивних матеріалів.

3 огляду на такі підходи, основними умовами досягнення ефективності використання методичних систем навчання фізики, у яких провідна роль відводиться інформаційно-комунікаційним технологіям, визначається забезпеченням впливу засобів IКТ на формування детермінант поведінки суб'єктів навчального процесу через засвоєння ними способів діяльності, що співвідноситься із конкретними засобами IКТ; створенням стійкої системи дидактичних вимог до педагогічних програмних засобів $\mathrm{i}$ узгодження їх представлення у свідомості окремих суб'єктів навчально-виховного процесу [10].

Такий підхід отримав підтвердження в роботах В. Ф. Заболотного, який довів, що однією 3 умов ефективного використання інформаційних технологій у навчальновиховному процесі з фізики є забезпечення підготовки учителів з якісно новим складом особистісних характеристик. Дослідник обгрунтував провідну роль IКТ у забезпеченні функціонування освітнього середовища в проекції на досягнення основних цілей шкільної фізичної освіти, а також формуванні методичної компетентності майбутніх учителів фізики. Ним запропоновано механізми реалізації системного підходу у використанні мультимедійних методів і засобів навчання фізики, проектуванні навчального освітнього середовища [6].

У розробленні проблеми окресленої стверджується новий дидактичний напрям обгрунтування провідної ролі ІКТ у формуванні загальнонавчальних і предметних компетентностей учнів загальноосвітньої і вищої професійної шкіл. Зокрема, реалізація освітньої галузі «Природознавство» Державного стандарту базової і повної загальної середньої освіти (2011р.), до якої входить фізичний компонент, передбачає не тільки опанування змісту фізичної освіти, a, у першу чергу, формування ключових i предметних компетентностей. Важливе значення надається як предметній компетентності з фізики, так і ключовій інформаційно-комунікаційній компетентності, зміст якої $\epsilon$ інтегративним, а формування відбувається у процесі вивчення всіх предметів навчального плану на засадах діяльнісного підходу [3].

3 огляду на це, своєчасним бачиться розгортання наукових досліджень щодо використання інформаційно-комунікаційних технологій як засобу формування компетентностей учнів у процесі навчання фізики. На сьогодні виконано перші дослідження проблеми формування предметної компетентності з фізики засобами IКТ. 
У дисертації О. М. Соколюк розвинула підходи щодо визначальної ролі IКТ у реалізації цілей особистісно орієнтованого навчання фізики, обгрунтовано необхідність розбудови комп'ютерно орієнтованого навчального середовища як важливої дидактичної умови реалізації моделі розвитку навчальних компетентностей учнів загальноосвітньої школи. Практичним результатом цих досліджень стала авторська методика розвитку контрольно-оцінювальних умінь старшокласників у процесі навчання фізики в умовах комп'ютерно орієнтованого середовища.

У дослідженнях О. П. Пінчук, узагальнених у 2011 році у кандидатській дисертації, експериментально доведено наявність значущого позитивного впливу на процес формування предметної компетентності з фізики в учнів основної школи методичних систем, які передбачають широке використання практико-орієнтованих ситуативних задач, елементів технології навчального портфоліо, інтерактивних технологій, комп'ютерно орієнтованих засобів навчання фізики. Запропонована автором методика формування предметних компетентностей 3 фізики засобами мультимедійних технологій передбачає функціонування навчального середовища, яке забезпечує формування у суб'єктів навчального процесу умотивованої потреби використовувати для розв'язання навчально-пізнавальних завдань різноманітних інформаційних джерел, що, у свою чергу, актуалізує доцільність системного використання 3 метою їх задоволення засобів мультимедійних технологій. Функціональна модель запропонованої методики передбачає органічне включення IКТ як складової комп'ютерно орієнтованого середовища до всіх основних етапів діяльності вчителя й учнів у процесі навчання фізики. Як один із важливих моментів обгрунтовується вплив інформаційно-комунікативних технологій на формування i корекцію предметної галузі з фізики в індивідуальній свідомості учнів [13].

Важливим напрямом є також розроблення методологічних засад формування інформаційно-комунікаційної компетентності як ключової у процесі навчання фізики в середній і вищій школах. Так у дослідженнях В. Ф. Заболотного розв'язується дидактична проблема формування інформаційно-комунікаційної компетентності майбутніх учителів фізики фахової підготовки, що дало можливість обгрунтувати іiі взаємозв'язки з предметними компетентностями і розвитком здатностей розв'язувати завдання на основі ретельного опрацювання наявних інформаційних ресурсів i комунікацій [7]. Обгрунтовується більш значущий вплив IКТ в організації навчання фізики в загальноосвітній і вищій школах, ніж традиційні підходи, згідно яких ці технології розглядаються переважно засобом підтримки навчальних курсів.

\section{4. ВИСНОВКИ ТА ПЕРСПЕКТИВИ ПОДАЛЬШИХ ДОСЛІДЖЕНЬ}

1. Історико-методичний аналіз особливостей запровадження інформаційнокомунікаційних технологій у навчально-виховний процес 3 фізики дає можливість зробити висновок про системний характер досліджень 3 наукового обгрунтування цього процесу. На початкових етапах основними дидактичними цілями використання засобів IКТ була комп'ютерна підтримка, зокрема, шкільного фізичного експерименту ia поглиблення реалізації принципу наочності у навчанні фізики. Наукові дослідження зосереджувалися переважно на розробленні комп'ютерного дидактичного забезпечення навчання фізики, яке давало можливість більш ефективно досягати навчальні цілі порівняно з традиційним підходами. Важливим результатом у цьому контексті стало створення системи засобів електронного навчального призначення (бібліотеки електронних наочностей, електронні підручники, віртуальні фізичні лабораторії) для забезпечення навчання фізики в 7-11 класах, які й до сьогодні широко використовуються у шкільній практиці. Важливе значення мали й теоретичні 
дослідження із запровадження монотехнологій комп'ютерного навчання фізики й обгрунтування дидактичних особливостей їх використання як педагогічних інновацій.

2. Зусиллями науковців і практиків проблема ІКТ в навчанні фізики поступово «переросла» технологічний підхід, за якого найбільш принциповими були питання обгрунтування співвідношення традиційних і комп'ютерно орієнтованих технологій i засобів навчання, а дидактика фізики намагалася вирішити питання щодо раціонального поєднання, наприклад, паперового й електронного підручника, реального і віртуального фізичного експерименту. Аналіз тематики дисертаційних досліджень 3 теорії і методики навчання фізики, виконаних за останні 20 років, у контексті досліджуваного питання, показує, що вони в цілому спрямовувалась саме на обгрунтування методичних систем, які поєднують традиційні i комп'ютерноорієнтовані моделі навчання фізики в загальноосвітній школі.

3. У сучасній дидактиці інформаційно-комунікаційні технології навчання фізики розглядаються не стільки як інструментальні засоби, а, у першу чергу, як методологія побудови нових методичних систем на основі новітніх технологій збирання, опрацювання, зберігання, відтворення та інтерпретації, передавання інформації, а також програмно-методичні комплекси, орієнтовані на досягнення цілей шкільної фізичної освіти, розв'язання важливих дидактичних задач. Такі технології $\epsilon$ важливими складовими нового інформаційно-комунікаційного середовища, яке наповнюється електронними науковими, освітніми та управлінськими інформаційними ресурсами, його ознакою є забезпечення суб' єктам освітнього процесу рівного доступу до ресурсів, засобів та сервісів [1].

4. Пріоритетними дидактичними цілями шкільної фізичної освіти є формування предметної компетентності i внесок у формування ключової інформаційнокомунікаційної компетентності. Тенденції науково обгрунтованого використання ІКТ у навчанні фізики дають можливість говорити про їх провідну роль у цьому процесі. Доцільним $є$ розгортання подальших наукових досліджень проблеми формування компетентностей учнів загальноосвітніх навчальних закладів і майбутніх учителів фізики у проекції на створення і розвиток інформаційно-комунікаційного середовища.

\section{СПИСОК ВИКОРИСТАНИХ ДЖЕРЕЛ}

1. Биков В. Ю. Моделі організаційних систем відкритої освіти : монографія. - К. : Атіка, 2008. - 684 c.

2. Бугайов О. І., Головко М. В., Коваль В. С. Концептуальні положення щодо розробки педагогічних програмних засобів з фізики (з досвіду створення програмно-методичного комплексу “Фізика 8" //Комп’ютер у школі та сім’ї . - № 8 (40). - 2004. - С. 13-16.

3. Державний стандарт базової і повної загальної середньої освіти [Електронний ресурс] . - К., 2011. - Режим доступу : http://zakon3.rada.gov.ua/laws/show/1392-2011.

4. Експеримент на екрані комп'ютера : монографія /авт. кол. Ю. О. Жук, С. П. Величко, О. М. Соколюк, І. В. Соколова, П. К. Соколов. За редакцією: Жука Ю. О -- К. : Педагогічна думка, 2012. - $180 \mathrm{c}$.

5. Електронний підручник майбутнього сьогодні реальність, завтра-необхідність / ]В. Ф. Заболотний, В. І. Сумський, Л. Л. Коношевський, Р. Б. Тичук] // Сучасні інформаційні технології та інноваційні методики навчання у підготовці фахівців: методологія, теорія, досвід, проблеми : зб. наук. пр. - Київ - Вінниця : ДОВ Вінниця, 2002. - С. 226-232.

6. Заболотний В. Ф. Дидактичні засади застосування мультимедіа у формуванні методичної компетентності майбутніх учителів фізики : автореф. дис. ... доктора пед. наук : 13.00.02 / В. Ф. Заболотний ; Нац. пед. ун-т ім. М. П. Драгоманова. - К., 2010. - 40 с.

7. Заболотний В. Ф. Інформаційно-комунікативна компетентність майбутнього учителя фізики / В.Ф. Заболотний // Вісник Чернігівського державного педагогічного університету імені Т. Г. Шевченка. Випуск 36. Серія: Педагогічні науки : збірник у 2-х т. - Чернігів : ЧДПУ, 2008 № 46. - T. 2. - C. 169-171. 
8. Жук Ю. О. Розв’язування дослідницьких задач з фізики із використанням нових інформаційних технологій : автореф. дис. ... канд. пед. наук : 13.00.02 / Ю. О. Жук ; Український педагогічний унт ім. М. П. Драгоманова. - К., 1995. - 20 с.

9. Іваницький О. І. Теоретичні і методичні основи підготовки майбутнього вчителя фізики до впровадження інноваційних технологій навчання автореф. дис. ... доктора пед. наук : 13.00 .02 / О. І. Іваницький ; Нац. пед. ун-т ім. М. П. Драгоманова. - К., 2005. - 43 с.

10. Комп’ ютерно орієнтовані засоби навчання з фізики в школі : посібник /авт. кол.: Ю. О. Жук, О. М. Соколюк, І. В. Соколова, П. К. Соколов / за заг. ред. Ю. О. Жука - К. : Педагогічна думка, 2011. $152 \mathrm{c}$.

11. Мультимедійні системи як засоби інтерактивного навчання: посібник / [Жалдак М. I., Шут М. I., Жук Ю.О., Дементієвська Н. П., Пінчук О. П., Соколюк О. М., Соколов П. К]. / за ред. Жука Ю. О. - К. : Педагогічна думка, 2012. - 112 с.

12. Організація навчальної діяльності у комп'ютерно орієнтованому навчальному середовищі: посібник / [Жук Ю. О., Соколюк О. М., Дементієвська Н. П., Пінчук О. П.] / за ред.: Жука Ю. О. К. : Педагогічна думка, 2012. - 128 с.

13. Пінчук О. П. Формування предметних компетентностей учнів основної школи в процесі навчання фізики засобами мультимедійних технологій : автореф. дис. ... канд. пед. наук : 13.00.02 / О. П. Пінчук; Нац. пед. ун-т ім. М.П.Драгоманова. - К., 2011. - 20 с.

14. Сумський В. І. Методика і теорія застосування ЕОМ у процесі вивчення фізики у педагогічних закладах : монографія. - Вінниця : ВДПУ, 2003. - 380 с.

Матеріал надійшов до редакиї 25.02.2015 p.

\title{
ГЕНЕЗИС ВНЕДРЕНИЯ ИНФОРМАЦИОННО-КОММУНИКАЦИОННЫХ ТЕХНОЛОГИЙ В ФИЗИЧЕСКОМ ОБРАЗОВАНИИ: ОТ КОМПЬЮТЕРНОЙ ПОДДЕРЖКИ ОБУЧЕНИЯ К ФОРМИРОВАНИЮ КЛЮЧЕВЫХ И ПРЕДМЕТНЫХ КОМПЕТЕНТНОСТЕЙ
}

\section{Головко Николай Васильевич}

кандидат педагогических наук, доцент, старший научный сотрудник, заместитель директора по научной работе

Институт педагогики НАПН Украины, г. Киев, Украина

m.golovko@ukr.net

\begin{abstract}
Аннотация. В статье на основе историко-методического анализа обосновываются особенности процесса внедрения информационно-коммуникационных технологий в обучение физики, развитии компьютерного дидактического обеспечения. Освещается развитие научных основ и механизмов их реализации в отечественной теории и методике обучения физике, влияние на формирование компьютерно-ориентированной среды и качественное изменение роли субъектов учебного процесса. Актуализируется целесообразность дальнейших дидактических исследований этой проблемы в связи с приоритетностью компьютерно-ориентированных технологий в формировании ключевых и предметной компетентности учащихся общеобразовательной и высшей школы в процессе обучения физике.
\end{abstract}

Ключевые слова: развитие теории и методики обучения физике; средства информационнокоммуникационных технологий; ключевые и предметные компетентности.

THE GENESIS OF THE IMPLEMENTATION OF THE INFORMATION AND COMMUNICATION TECHNOLOGIES IN PHYSICS EDUCATION: FROM ITSUPPORT OF STUDYING TO THE FORMATION OF THE KEY AND THE SUBJECT COMPETENCES

\author{
Mykola V. Holovko \\ $\mathrm{PhD}$ (pedagogical sciences), associate professor, senior researcher, Deputy Director for Science \\ Institute of Pedagogy of the NAES of Ukraine, Kyiv, Ukraine. \\ m.golovko@ukr.net
}




\begin{abstract}
In the article, the peculiarities of the process of the implementation of the information and communication technologies in teaching Physics, the development of the computer didactic provision are specified on the basis of the historical and methodological analysis. The development of the scientific fundamentals and the tools of their implementation in the homeland theory and methodology of teaching Physics, the impact of the formation of the computer-oriented environment as well as the qualitative change in the academic process subjects' role are demonstrated. The necessity of the further didactic researches on the abovementioned issue because of the priority of the computer-oriented technologies in the formation of the key and the subject competences of the comprehensive and high school pupils in the process of Physics teaching are actualized.
\end{abstract}

Keywords: the development of the theory and the methodology of teaching Physics; means of information and communication technologies; key and subject competences.

\title{
REFERENCES (TRANSLATED AND TRANSLITERATED)
}

1. Bykov V. Yu. Models of organizational Open Education Monograph. - K. : Atika, 2008. - 684 s. (in Ukrainian).

2. Buhaiov O. I., Holovko M. V., Koval V. S. Conceptual provisions for developing educational software in Physics (with experience in creating software and methodical complex "Physics 8" //Kompiuter u shkoli ta simi. - \# 8 (40). - 2004. - S. 13-16 (in Ukrainian).

3. State Standard of full secondary education [online]. - K., 2011. - Available from : http://zakon3.rada.gov.ua/laws/show/1392-2011 (in Ukrainian).

4. Experiment on the computer screen : monograph /avt. kol. Yu. O. Zhuk, S. P. Velychko, O. M. Sokoliuk, I. V. Sokolova, P. K. Sokolov. Za redaktsiieiu: Zhuka Yu. O. - K. : Pedahohichna dumka, 2012. - 180 s. (in Ukrainian).

5. Electronic textbook of the future: the requirement of reality, today, tomorrow / V. F. Zabolotnyi, V. I. Sumskyi, L. L. Konoshevskyi, R. B. Tychuk // Suchasni informatsiini tekhnolohii ta innovatsiini metodyky navchannia u pidhotovtsi fakhivtsiv: metodolohiia, teoriia, dosvid, problemy: zb. nauk. pr. Kyiv - Vinnytsia : DOV Vinnytsia, 2002. - S. 226-232 (in Ukrainian).

6. Zabolotnyi V. F. Didactic principles of application of multimedia in the formation of methodical competence of future physics teachers: Author. Thesis. ... Dr. ped. Sciences : 13.00.02 / V. F. Zabolotnyi ; Nats. ped. un-t im. M.P.Drahomanova. - K., 2010. - 40 s. (in Ukrainian).

7. Zabolotnyi V. F. Information and communicative competence of the teacher of physics / V. F. Zabolotnyi // Visnyk Chernihivskoho derzhavnoho pedahohichnoho universytetu imeni T. H. Shevchenka. Vypusk 36. Seriia: Pedahohichni nauky: Zbirnyk u 2-kh t. - Chernihiv : ChDPU, 2008 - \# 46. - T. 2. - S. 169171 (in Ukrainian).

8. Zhuk Yu. O. Solving problems in physics research using new information technologies: Author. Thesis ... candidate. ped. Science: 13.00.02 / Yu. O. Zhuk ; Ukrainskyi pedahohichnyi un-t im. M.P. Drahomanova. - K., 1995. - 20 s. (in Ukrainian).

9. Ivanytskyi O. I. Theoretical and methodological foundations of future teacher of physics to the introduction of innovative learning technologies: Author. dis ... Dr. ped. Sciences: 13.00.02 / O. I. Ivanytskyi ; Nats. ped. un-t im. M.P.Drahomanova. - K., 2005. - 43 s. (in Ukrainian).

10. Computer-oriented learning tools in physics in school: Manual /avt. kol.: Yu. O. Zhuk, O. M. Sokoliuk, I. V. Sokolova, P. K. Sokolov / za zah. red. Yu. O. Zhuka. - K. : Pedahohichna dumka, 2011. - 152 s. (in Ukrainian).

11. Multimedia systems as a means of interactive learning: Manual / avt. Zhaldak M. I., Shut M. I., Zhuk Yu. O., Dementiievska N. P., Pinchuk O. P., Sokoliuk O. M., Sokolov P. K. / Za redaktsiieiu: Zhuka Yu. O. K. : Pedahohichna dumka, 2012. - 112 s. (in Ukrainian).

12. The organization of training activities in computer-oriented learning environment: Manual /avt.: Zhuk Yu. O., Sokoliuk O. M., Dementiievska N. P., Pinchuk O. P. / Za redaktsiieiu: Zhuka Yu. O. - K. : Pedahohichna dumka, 2012. - 128 s. (in Ukrainian).

13. Pinchuk O. P. Formation of subject competencies of primary school students in learning physics by means of multimedia technologies: Author. Thesis ... candidate. ped. Sciences: 13.00.02 / O. P. Pinchuk; Nats. ped. un-t im. M. P. Drahomanova. - K., 2011. - 20 s. (in Ukrainian).

14. Sumskyi V. I. Methodology and Theory of computer applications in the study of physics teaching in schools : Monograph. - Vinnitsa : BDPU, 2003. - 380 s. (in Ukrainian). 